\title{
Nutritional impact of inclusion of garlic (Allium sativum) and/or onion (Allium cepa L.) powder in laying hens' diets on their performance, egg quality, and some blood constituents
}

Hamed A. A. Omer', Sawsan M. Ahmed', Soha S. Abdel-Magid ${ }^{1 *}$, Gamal M. H. El-Mallah'1, Adel A. Bakr² and Magda M. Abdel Fattah ${ }^{3}$

\begin{abstract}
Background: Many studies mentioned that using medicinal herbs and plants as feed additives to ruminants seems to be a recent trend depending on the availability and their cost but using them with monogastric animals and birds, as pharmaceutical tool, is available. As an example, the importance of garlic or onion in recent years, thanks to a wide range of useful properties, has been increasingly used as an additive in nutrition and protection of farm animals. Their action was manifested in a reduced expanding range of pathogenic microorganisms in the digestive tract, which resulted in the rapid growth of poultry, efficient digestion, and increased immunity and health of poultry.

Methods: One hundred and eight 30-week-old laying hens were randomly divided into six dietary treatment groups $\left\{G_{1}\right.$ control, $G_{2}$ contained $0.5 \%$ garlic powder (GP), $G_{3}$ contained $1 \% \mathrm{GP}_{,} \mathrm{G}_{4}$ contained $1 \%$ onion powder (OP), $\mathrm{G}_{5}$ contained $1 \% \mathrm{OP}+0.5 \% \mathrm{GP}$, and $\mathrm{G}_{6}$ contained $\left.1 \% \mathrm{OP}+1 \% \mathrm{GP}\right\}$. Each group included 18 hens in six replicates (3 birds/each). So, this work carried out to investigate the impact of incorporating garlic powder (GP) and/or onion powder (OP) in laying hens' diets on their performance, egg quality, and some blood constituents.

Results: Incorporating GP, OP, and the mixture of them in laying hen diets had no significant effect on the average egg weight and consumption/hen/day throughout the three stages of egg collection, but had a significant improvement in the number of eggs/hen, percentage of egg production, egg mass/hen, and feed conversion. Inclusion of GP, OP, or the mixture of them in laying hen diets had no significant effect on the shape index, Haugh unit, albumin, and shell percentages; also, an insignificant increase for shell thickness was observed, but egg weight increases $(P<0.05)$. Incorporation of GP, OP, and the mixture of them significantly decreased $(P<0.05)$ total cholesterol concentration. Also, an inclusion of $0.5 \% \mathrm{GP}, 1 \% \mathrm{GP}$, and $1 \% \mathrm{OP}+1 \% \mathrm{GP}$ decreased $(P<0.05)$ high-density lipoprotein. Inclusion of only $1 \% \mathrm{OP}+1 \% \mathrm{GP}\left(\mathrm{G}_{6}\right)$ decreased $(P<0.05)$ glutamic oxaloacetic transaminase; meanwhile, supplementation of $1 \% \mathrm{OP}, 1 \% \mathrm{OP}+0.5 \% \mathrm{GP}$, or $1 \% \mathrm{OP}+1 \% \mathrm{GP}$ increased $(P<0.05)$ creatinine.
\end{abstract}

Conclusion: From the results obtained and under conditions suitable for this study, it can be mentioned that the incorporation of garlic or onion powder or the mixture of them can be safely used with improvement in the general health of hens, egg weight, and feed conversion and decrease in the blood cholesterol.

Keywords: Laying hens, Garlic, Onion, Performance, Egg quality, Blood plasma constituents

\footnotetext{
* Correspondence: soha_syd@yahoo.com

${ }^{1}$ Animal Production Department, National Research Centre, 33 El-Bohouth

Street, P.O: 12622, Dokki, Cairo, Egypt

Full list of author information is available at the end of the article
} 


\section{Background}

Numerous therapeutic and prophylactic properties have been ascribed to garlic (Allium sativum) and onion (Allium capa L.) for thousands of years, dating from such ancient civilizations as the Egyptians, Greeks, and Chinese (Kendler 1987).

Using medicinal herbs and plants as feed additives to ruminants seems to be a recent trend depending on the availability and their cost, but using them with monogastric animals and birds, as pharmaceutical tool, is available.

Garlic and onion have a stimulating effect on the gastric system (Dewit et al. 1979), while Rode et al. (1989) found that garlic extract has bactericidal effects against gram-negative organisms tested. Also, garlic oil had the anthelmintic activity on common poultry worms Ascaridia galli and Hetrakis gallinae (Kavindra et al. 2000).

Garlic action was manifested in a reduced expanding range of pathogenic microorganisms in the digestive tract, which resulted in the rapid growth of poultry, efficient digestion, and increased immunity and health of poultry (Kumar et al. 2010).

Garlic has beneficial effects on chickens: antimicrobial and antioxidant and reduced mortality and increased secretion in the stomach (Konjufca et al. 1997; Sivam 2001; Stanaćev et al. 2010).

The garlic contains important organic sulfurous compounds aliin, allicin, ajoene and allylpropyl disulphide and diallyl trisulphide, sallilcisteine, and others (Freeman and Kodera 1995; Kemper 2000; Mansoub 2011). Also, garlic contains enzymes ( $\alpha$-allinase, peroxydase, myrosinase, etc.), amino acids and their glycosides (arginine and others), vitamins (C, E, A, D, and B group vitamins), and minerals (iodine, potassium, sodium, calcium, magnesium, selenium, silicon, phosphorus) (Grela and Klebaniuk 2007; Popić 2009).

On the other hand, Hanafy et al. (1994) found that lead concentrations were reduced in muscles and liver tissues of chickens that were given garlic.

Adding garlic at different levels $(0,1000,1500,3000$, and $10,000 \mathrm{mg} / \mathrm{kg}$ ) in horse diets caused an increasing in feed palatability (Horton et al. 1991).

Abdullah et al. (2010) noticed that diets supplemented with $0.5 \%$ and $1 \%$ garlic powder caused decreasing broiler chicken feed consumption.

Garlic was reported to enhance performance of laying hens and improve egg quality when supplemented in diet (Lim et al. 2006; Yalcin et al. 2006; Khan et al. 2007).

Onion and garlic had valuable nutrients such as vitamins, minerals, and essential amino and fatty acids (Hariedy 1977). Also, onion and garlic are widely suggested to be used in animal feeding to stimulate growth (Koremura et al. 1984; Osman et al. 1997 and El-feel et al. 1999). Also, onion has a beneficial effect in lowering the level of cholesterol in blood plasma or serum of domestic fowls (Abdo et al. 1983 and El-Nawawi 1991).

Onion bulbs possess numerous organic sulfur compounds including trans-S-(1-propenyl) cysteine sulfoxide, S-methyl-cysteine sulfoxide, spropylcycteine sulfoxides, and cycloallicin, flavinoids, phenolic acids, sterols including cholesterol, stigma sterol, b-sitosterol, saponins, sugars, and a trace of volatile oil compounds mainly of sulfur compounds (Melvin et al. 2009). Most of the plant parts contain compounds with proven antibacterial, antiviral, antiparasitic, and anti-fungal properties and have antihypertensive, hypoglycemic, antithrombotic, antihyperlipidemic, anti-inflammatory, and antioxidant activities (Lampe 1999).

Goodarzi et al. (2013) recorded that using onion bulbs in broiler diet can decrease triglyceride and total cholesterol in blood serum.

So, this work aimed to investigate the impact of adding garlic and/or onion powders on the performance, blood plasma, and egg quality of commercial laying hens.

\section{Methods}

One hundred and eight 30-week-old commercial Bovan Brown layers were housed in individual wire cages and divided into six equal treatment groups of 18 hens each (six replicates of three birds each). All hens were kept under the same managerial, hygienic, and environmental temperature which ranged from 22 to $38^{\circ} \mathrm{C}$ and humidity from 40 to $60 \%$ during over all the experimental intervals (three periods of 4 weeks each). Also, the lighting schedule was $16 \mathrm{~h}$ light: $8 \mathrm{~h}$ dark/day. Hens received an iso-caloric and iso-nitrogenous $(2750 \mathrm{ME} \mathrm{kcal} / \mathrm{kg}$ and $17 \% \mathrm{CP})$ diets.

The experimental diets consisted of antibiotic-free layer mash formulated to meet the nutrient requirement for layers as established by NRC (1994). The compositions of different experimental rations are presented in Table 1.

Both garlic (Allium sativum) and onion (Allium capa $L$.) powders were bought from the local market and incorporated in the experimental rations as follows:

$\mathrm{G}_{1}$ : ration diet no contained any feed additive and assigned as control ration

$\mathrm{G}_{2}$ : ration contained $0.5 \%$ garlic powder $(\mathrm{GP})$ or $(5 \mathrm{~g}$ $\mathrm{GP} / \mathrm{kg}$ feed)

$\mathrm{G}_{3:}$ ration contained $1.0 \%$ garlic powder (GP) or (10 g $\mathrm{GP} / \mathrm{kg}$ feed)

$\mathrm{G}_{4}$ : ration contained $1.0 \%$ onion powder $(\mathrm{OP})$ or $(10 \mathrm{~g}$ $\mathrm{OP} / \mathrm{kg}$ feed)

$\mathrm{G}_{5}$ : ration $1.0 \% \mathrm{OP}+0.5 \% \mathrm{GP}$ or $(10 \mathrm{~g}$ onion $+5 \mathrm{~g}$ garlic powder/ kg feed)

$\mathrm{G}_{6 \text { : }}$ ration contained $1.0 \% \mathrm{OP}+1.0 \% \mathrm{GP}$ or $10 \mathrm{~g}$ onion $+10 \mathrm{~g}$ garlic powder $/ \mathrm{kg}$ feed 
Table 1 Composition and calculated chemical analysis of different experimental rations

\begin{tabular}{|c|c|c|c|c|c|c|}
\hline Ingredients & $\mathrm{G}_{1}$ & $\mathrm{G}_{2}$ & $\mathrm{G}_{3}$ & $\mathrm{G}_{4}$ & $\mathrm{G}_{5}$ & $\mathrm{G}_{6}$ \\
\hline \multicolumn{7}{|l|}{ 1. Composition } \\
\hline Yellow corn & 64.00 & 63.68 & 63.37 & 63.37 & 63.00 & 62.75 \\
\hline Soybean meal & 23.50 & 23.32 & 23.13 & 23.13 & 23.00 & 22.75 \\
\hline Garlic powder & 0.00 & 0.50 & 1.00 & 0.00 & 0.50 & 1.00 \\
\hline Onion powder & 0.00 & 0.00 & 0.00 & 1.00 & 1.00 & 1.00 \\
\hline Protein concentrates & 3.00 & 3.00 & 3.00 & 3.00 & 3.00 & 3.00 \\
\hline Dicalcium phosphate & 1.50 & 1.50 & 1.50 & 1.50 & 1.50 & 1.50 \\
\hline Lime stone & 7.50 & 7.50 & 7.50 & 7.50 & 7.50 & 7.50 \\
\hline Methionine & 0.05 & 0.05 & 0.05 & 0.05 & 0.05 & 0.05 \\
\hline Mineral and vitamin premix & 0.20 & 0.20 & 0.20 & 0.20 & 0.20 & 0.20 \\
\hline Sodium chloride & 0.25 & 0.25 & 0.25 & 0.25 & 0.25 & 0.25 \\
\hline \multicolumn{7}{|l|}{ 2. Chemical analysis } \\
\hline Moisture & 6.49 & 6.48 & 6.45 & 6.45 & 6.44 & 6.41 \\
\hline \multicolumn{7}{|l|}{ Chemical analysis on dry matter basis } \\
\hline Organic matter (OM) & 88.44 & 88.43 & 88.43 & 88.43 & 88.41 & 88.42 \\
\hline Crude protein (CP) & 17.64 & 17.57 & 17.50 & 17.49 & 17.44 & 17.35 \\
\hline Crude fiber (CF) & 3.73 & 3.73 & 3.74 & 3.75 & 3.74 & 3.75 \\
\hline Ether extract (EE) & 3.11 & 3.10 & 3.09 & 3.09 & 3.08 & 3.07 \\
\hline Nitrogen-free extract (NFE) & 63.96 & 64.03 & 64.10 & 64.10 & 64.15 & 64.25 \\
\hline Ash & 11.56 & 11.57 & 11.57 & 11.57 & 11.59 & 11.58 \\
\hline Metabolizable energy, (kcal/kg DM) & 2779 & 2778 & 2776 & 2776 & 2775 & 2773 \\
\hline
\end{tabular}

Metabolizable energy (kcal/kg DM) was calculated according to NRC (1994)

$G_{1}$ control, $G_{2}$ contained $0.5 \%$ garlic powder, $G_{3}$ contained $1 \%$ garlic powder, $G_{4}$ contained $1 \%$ onion powder, $G_{5}$ contained $1 \%$ onion powder $+0.5 \%$ garlic powder, $G_{6}$ contained $1 \%$ onion powder $+1 \%$ garlic powder

Feed and water were offered ad libitum. Egg weight (EW) and egg number (EN) were recorded daily. Feed intake (FI) was recorded weekly, while feed conversion ratios (FCR) were calculated.

Egg quality parameters were measured using 36 eggs (6 eggs/each group); these involved yolk, albumen, and shell weight (\%). Egg shell thickness was measured in millimeter using a micrometer as described by Günlü et al. (2003). Egg shape index was calculated as egg diameter divided by an egg length as described by Anderson et al. (2004). Yolk index was calculated as yolk height divided by the yolk diameter. Haugh unit was calculated using the calculation chart for rapid conversion of EW and albumen height as described by Doyon et al. (1986).

\section{Analytical procedures}

Chemical analysis of feed ingredients was analyzed according to AOAC (2005) methods.

At the end of the third stage of egg collection, blood samples were collected from the wing vein of laying hens using sterilized syringes and needles. Collected blood samples were centrifuged at $4000 \mathrm{rpm}$ for $20 \mathrm{~min}$, for the preparation of blood plasma. Plasma was kept frozen at $-18^{\circ} \mathrm{C}$ for subsequent analysis.
Various blood plasma parameters were calorimetrically determined using commercial kits, following the same steps as described by the manufacturers.

Plasma total protein was determined according to Armstrong and Carr (1964) and Witt and Trendelenburg (1982) and albumin according to Doumas et al. (1971) and (Tietz 1986); globulin was calculated by subtracting the albumin value from total protein value; total cholesterol was determined according to Allain et al. (1974) and Pisani et al. (1995); alkaline phosphate activity was measured according to the method of Beliefield and Goldberg (1971); plasma glutamic oxaloacetic transaminase (GOT) and glutamic pyruvic transaminase (GPT) activities were determined as described by Reitman and Frankel (1957) and Harold (1975) and creatinine as described by Husdan (1968); high-density lipoprotein (HDL) concentration was estimated according to Assmann (1979). Also, albumin to globulin ratio (A:G ratio) was calculated.

\section{Statistical analysis}

Data collected were subjected to statistical analysis as one-way analysis of variance according to SPSS (2008). Duncan's multiple range test (Duncan 1955) was used to 
separate means when the dietary treatment effect was significant according to the following model:

$$
\begin{gathered}
Y_{i j}=\mu+T_{i}+e_{i j} \\
\text { where } Y_{i j}=\text { observation }
\end{gathered}
$$

$\mu=$ overall mean

$T_{i}=$ effect of experimental rations for $i=1-6,1=$ laying hens received ration not contained any feed additive, 2

$=$ laying hens received ration contained $0.5 \%$ garlic powder, 3 = laying hens received diet contained $1 \%$ garlic powder, $4=$ laying hens received ration contained $1 \%$ onion powder, $5=$ laying hens received ration contained $1 \%$ onion powder $+0.5 \%$ garlic powder and $6=$ laying hens received ration contained $1 \%$ onion powder $+1 \%$ garlic powder $e_{i j}=$ the experimental error

\section{Results}

\section{Chemical analysis (\%) of feed ingredients}

Garlic powder contains $8.37 \% \mathrm{CP}, 4.68 \% \mathrm{CF}, 0.85 \% \mathrm{EE}$, $83.35 \%$ NFE, and $4.35 \%$ ash; on the other hand, the value of metabolizable energy was $2838 \mathrm{kcal} / \mathrm{kg}$ DM feed. Meanwhile, the corresponding values of the same nutrients determined in onion powder were 6.84, 5.72, 0.74, 82.35 , and $4.35 \%$ for CP, CF, EE, NFE, and ash contents, respectively (Table 2 ).

\section{Performance}

Incorporating GP, OP, and the mixture of them in laying hen diets had no significant effect on the egg weight throughout the first, second, and third (except $\mathrm{G}_{6}$ ) stages of egg collection. Also, it had no significant effect on feed consumption/hen/day throughout the three stages of egg collection. On the other hand, feed conversion significantly $(P<0.05)$ improved (Table 3$)$.

\section{Egg production}

Data illustrated in Table 3 showed that inclusion of GP, $\mathrm{OP}$, and the mixture of them in laying hen diets caused significant improvement in the number of eggs/hen, percentage of egg production, and egg mass/hen throughout the three stages of egg collection. Egg production and quality are heritable traits of major concern for breeders and consumers. To improve these characteristics, correct nutritional, management, and environmental practices are needed to enhance egg production and quality.

\section{Egg quality}

Dietary treatments significantly increased $(P<0.05)$ the egg weight that ranged from 60.60 to $64.60 \mathrm{~g}$ in comparison with the control $(55.40 \mathrm{~g})$, while no significant effect on shape index, Haugh unit, albumin, and shell percentages; also, an insignificant increase for shell thickness was observed (Table 4).

Yolk index increased $(P<0.05)$ for laying hen receiving ration containing $1 \% \mathrm{OP}+1 \% \mathrm{GP}\left(\mathrm{G}_{6}\right)$ compared to control (49.10 vs. 43.30). Values of yolk color were approximately in the same trend (5.00) for $G_{2}, G_{4}, G_{5}$, and $\mathrm{G}_{6}$, which are less than those of the control group that recorded (5.20); meanwhile, $G_{3}$ recorded the lowest value $(P<0.05)$ of yolk color $(4.80)$.

\section{Blood plasma constituents}

Data of Table 5 showed that incorporating 1\% GP in laying hen diets $\left(G_{3}\right)$ significantly $(P<0.05)$ decreased total protein compared to the control one, while the other dietary treatments $\left(G_{2}, G_{4}, G_{5}\right.$, and $\left.G_{6}\right)$ are not affected. On the other hand, except for $G_{3}$, the other dietary treatments $\left(\mathrm{G}_{2}, \mathrm{G}_{4}, \mathrm{G}_{5}\right.$, and $\left.\mathrm{G}_{6}\right)$ significantly $(P<0.05)$ increased albumin content. Moreover, globulin content was decreased with adding GP, OP, or the mixture of them; the lower value of globulin was recorded by laying hens that received $1 \%$ OP $+1 \%$ GP $\left(2.35, G_{6}\right)$ followed by birds that received $1 \%$ GP $\left(3.00, G_{3}\right)$. Laying hens fed rations contained mixture of $\mathrm{GP}+\mathrm{OP}\left(\mathrm{G}_{5}\right.$ and $\left.\mathrm{G}_{6}\right)$ recorded the highest values of albumin to globulin ratio $(P<0.05)$.

\begin{tabular}{|c|c|c|c|c|c|}
\hline Item & Yellow corn (YC) & Soybean meal (SBM) & Garlic powder (GP) & Onion powder (OP) & Protein concentrations \\
\hline Moisture & 7.35 & 6.39 & 3.41 & 2.75 & 3.05 \\
\hline \multicolumn{6}{|l|}{ Chemical analysis on DM basis } \\
\hline $\mathrm{OM}$ & 98.61 & 94.84 & 96.45 & 95.65 & 92.72 \\
\hline $\mathrm{CP}$ & 9.22 & 44.00 & 8.37 & 6.84 & 45.00 \\
\hline CF & 4.07 & 4.41 & 4.68 & 5.72 & 2.96 \\
\hline $\mathrm{EE}$ & 4.51 & 0.77 & 0.85 & 0.74 & 1.49 \\
\hline NFE & 80.81 & 45.66 & 82.55 & 82.35 & 43.27 \\
\hline Ash & 1.39 & 5.16 & 3.55 & 4.35 & 7.28 \\
\hline Metabolizable energy (kcal/kg DM)* & 3038 & 3152 & 2838 & 2795 & 3129 \\
\hline
\end{tabular}

Table 2 Chemical analysis (\%) of feed ingredients

*Metabolizable energy (kcal/kg DM) was calculated according to NRC (1994) 
Table 3 Effect of dietary treatments on laying hen performance

\begin{tabular}{|c|c|c|c|c|c|c|}
\hline Item & $\begin{array}{l}\text { Number of } \\
\text { egg/hen }\end{array}$ & $\begin{array}{l}\text { Percentage of } \\
\text { egg production }\end{array}$ & Egg mass/hen (g) & Average of egg weight (g) & Feed consumption/hen/day & Feed conversion \\
\hline \multicolumn{7}{|l|}{ First period (28 days) } \\
\hline $\mathrm{G}_{1}$ & $22.20^{\mathrm{b}}$ & $79.29^{b}$ & $1265.07^{b}$ & 56.94 & 119.71 & $2.63^{\mathrm{a}}$ \\
\hline $\mathrm{G}_{2}$ & $24.08^{\mathrm{a}}$ & $85.98^{\mathrm{a}}$ & $1394.75^{a}$ & 57.93 & 124.10 & $2.44^{\mathrm{ab}}$ \\
\hline $\mathrm{G}_{3}$ & $24.02^{\mathrm{a}}$ & $85.77^{\mathrm{a}}$ & $1355.08^{\mathrm{ab}}$ & 56.47 & 122.01 & $2.42^{b}$ \\
\hline $\mathrm{G}_{4}$ & $24.22^{\mathrm{a}}$ & $86.51^{\mathrm{a}}$ & $1381.71^{a}$ & 57.01 & 122.38 & $2.42^{\mathrm{b}}$ \\
\hline $\mathrm{G}_{5}$ & $24.34^{\mathrm{a}}$ & $86.94^{\mathrm{a}}$ & $1417.46^{\mathrm{a}}$ & 58.26 & 129.74 & $2.45^{\mathrm{ab}}$ \\
\hline $\mathrm{G}_{6}$ & $23.69^{a}$ & $84.60^{a}$ & $1356.75^{\mathrm{ab}}$ & 57.23 & 125.37 & $2.62^{\mathrm{ab}}$ \\
\hline Overall mean $\pm \mathrm{SE}$ & $23.76 \pm 0.23$ & $84.85 \pm 0.82$ & $1361.80 \pm 15.69$ & $57.31 \pm 0.31$ & $123.88 \pm 1.31$ & $2.49 \pm 0.03$ \\
\hline \multicolumn{7}{|c|}{ Second period (28 days) } \\
\hline $\mathrm{G}_{1}$ & $22.86^{c}$ & $75.60^{c}$ & $1326.21^{c}$ & 58.01 & 128.44 & $2.72^{\mathrm{a}}$ \\
\hline $\mathrm{G}_{2}$ & $24.57^{\mathrm{ab}}$ & $81.25^{\mathrm{ab}}$ & $1466.08^{\mathrm{ab}}$ & 59.68 & 129.96 & $2.49^{\mathrm{bc}}$ \\
\hline $\mathrm{G}_{3}$ & $25.89^{\mathrm{a}}$ & $85.62^{a}$ & $1505.41^{\mathrm{a}}$ & 58.22 & 122.95 & $2.29^{c}$ \\
\hline $\mathrm{G}_{4}$ & $24.81^{\mathrm{ab}}$ & $82.04^{\mathrm{ab}}$ & $1478.12^{\mathrm{ab}}$ & 59.57 & 125.98 & $2.39^{b c}$ \\
\hline $\mathrm{G}_{5}$ & $23.40^{\mathrm{bc}}$ & $77.38^{\mathrm{bc}}$ & $1391.74^{\mathrm{bc}}$ & 59.49 & 128.82 & $2.59^{a b}$ \\
\hline $\mathrm{G}_{6}$ & $25.05^{a}$ & $82.84^{\mathrm{a}}$ & $1471.52^{\mathrm{a}}$ & 58.67 & 123.25 & $2.37^{\mathrm{bc}}$ \\
\hline Overall mean \pm SE & $24.43 \pm 0.25$ & $80.79 \pm 0.84$ & $1439.85 \pm 16.71$ & $58.94 \pm 0.31$ & $126.57 \pm 1.14$ & $2.47 \pm 0.04$ \\
\hline \multicolumn{7}{|l|}{ Third period (28 days) } \\
\hline $\mathrm{G}_{1}$ & $21.84^{\mathrm{b}}$ & $72.22^{b}$ & $1278.72^{b}$ & $58.55^{b}$ & 124.26 & $2.73^{\mathrm{a}}$ \\
\hline $\mathrm{G}_{2}$ & $24.36^{a}$ & $80.56^{a}$ & $1502.66^{\mathrm{a}}$ & $61.60^{\mathrm{ab}}$ & 126.76 & $2.37^{b}$ \\
\hline $\mathrm{G}_{3}$ & $25.47^{\mathrm{a}}$ & $84.23^{a}$ & $1525.08^{a}$ & $59.88^{\mathrm{ab}}$ & 124.26 & $2.29^{b}$ \\
\hline $\mathrm{G}_{4}$ & $23.97^{\mathrm{a}}$ & $79.27^{a}$ & $1453.98^{\mathrm{a}}$ & $60.62^{\mathrm{ab}}$ & 125.44 & $2.43^{b}$ \\
\hline $\mathrm{G}_{5}$ & $23.79^{a}$ & $78.67^{\mathrm{a}}$ & $1463.28^{a}$ & $61.46^{\mathrm{ab}}$ & 125.98 & $2.42^{b}$ \\
\hline $\mathrm{G}_{6}$ & $24.93^{\mathrm{a}}$ & $82.44^{\mathrm{a}}$ & $1558.63^{\mathrm{a}}$ & $62.37^{\mathrm{a}}$ & 128.66 & $2.33^{b}$ \\
\hline Overall mean \pm SE & $24.06 \pm 0.30$ & $79.56 \pm 0.99$ & $1463.72 \pm 24.79$ & $60.75 \pm 0.44$ & $125.89 \pm 1.03$ & $2.43 \pm 0.04$ \\
\hline
\end{tabular}

$\mathrm{a}, \mathrm{b}$, and $\mathrm{c}$ : means in the same column having different superscripts differ significantly $(P<0.05)$

SEM standard error of mean, $G_{1}$ control, $G_{2}$ contained $0.5 \%$ garlic powder, $G_{3}$ contained $1 \%$ garlic powder, $G_{4}$ contained $1 \%$ onion powder, $G_{5}$ contained $1 \%$ onion powder $+0.5 \%$ garlic powder, $G_{6}$ contained $1 \%$ onion powder $+1 \%$ garlic powder

Table 4 Effect of dietary treatments on egg quality of laying hens

\begin{tabular}{llllllll}
\hline Item & $\mathrm{G}_{1}$ & $\mathrm{G}_{2}$ & $\mathrm{G}_{3}$ & $\mathrm{G}_{4}$ & $\mathrm{G}_{5}$ & $\mathrm{G}_{6}$ & Overall mean $\pm \mathrm{SE}$ \\
\hline Egg weight & $55.40^{\mathrm{b}}$ & $64.60^{\mathrm{a}}$ & $60.60^{\mathrm{ab}}$ & $63.80^{\mathrm{a}}$ & $63.40^{\mathrm{a}}$ & $62.40^{\mathrm{a}}$ & $61.70 \pm 0.89$ \\
Shape index & 75.44 & 76.91 & 76.81 & 62.50 & 75.12 & 77.65 & $74.07 \pm 2.48$ \\
Yolk index & $43.30^{\mathrm{b}}$ & $46.27^{\mathrm{ab}}$ & $45.19^{\mathrm{ab}}$ & $44.44^{\mathrm{ab}}$ & $43.80^{\mathrm{b}}$ & $49.10^{\mathrm{a}}$ & $45.35 \pm 0.70$ \\
Haugh unit & 86.80 & 80.80 & 83.40 & 86.60 & 86.40 & 80.60 & $84.10 \pm 0.98$ \\
Yolk color & $5.20^{\mathrm{a}}$ & $5.00^{\mathrm{ab}}$ & $4.80^{\mathrm{b}}$ & $5.00^{\mathrm{ab}}$ & $5.00^{\mathrm{ab}}$ & $5.00^{\mathrm{ab}}$ & $5.00 \pm 0.05$ \\
Shell thickness & 28.80 & 36.20 & 30.40 & 33.40 & 33.00 & 29.00 & $31.80 \pm 1.08$ \\
Albumin \% ${ }^{1}$ & 62.72 & 62.23 & 62.09 & 61.60 & 60.26 & 61.54 & $61.74 \pm 0.48$ \\
Yolk \% $^{1}$ & $26.10^{\mathrm{ab}}$ & $24.16^{\mathrm{b}}$ & $26.79^{\mathrm{ab}}$ & $25.16^{\mathrm{ab}}$ & $27.14^{\mathrm{a}}$ & $26.29^{\mathrm{ab}}$ & $25.94 \pm 0.38$ \\
Shell \% $^{1}$ & 11.18 & 13.61 & 11.12 & 13.25 & 12.59 & 12.17 & $12.32 \pm 0.38$ \\
\hline
\end{tabular}

$\mathrm{a}$ and b: means in the same row having different superscripts differ significantly $(P<0.05)$

SEM standard error of mean, $G_{1}$ control, $G_{2}$ contained $0.5 \%$ garlic powder, $G_{3}$ contained $1 \%$ garlic powder, $G_{4}$ contained $1 \%$ onion powder, $G_{5}$ contained $1 \%$ onion powder $+0.5 \%$ garlic powder, $G_{6}$ contained $1 \%$ onion powder $+1 \%$ garlic powder

${ }^{1}$ Percentage of egg weight 
Table 5 Effect of dietary treatments on some blood plasma constituents of laying hens

\begin{tabular}{llllllll}
\hline Item & $\mathrm{G}_{1}$ & $\mathrm{G}_{2}$ & $\mathrm{G}_{3}$ & $\mathrm{G}_{4}$ & $\mathrm{G}_{5}$ & $\mathrm{G}_{6}$ & Overall meal $\pm \mathrm{SE}$ \\
\hline Total protein, g/dL & $7.35^{\mathrm{a}}$ & $6.40^{\mathrm{ab}}$ & $5.25^{\mathrm{b}}$ & $7.30^{\mathrm{a}}$ & $6.65^{\mathrm{ab}}$ & $5.50^{\mathrm{ab}}$ & $6.41 \pm 0.28$ \\
Albumin, g/dL & $2.45^{\mathrm{bc}}$ & $3.30^{\mathrm{a}}$ & $2.25^{\mathrm{c}}$ & $3.25^{\mathrm{a}}$ & $3.35^{\mathrm{a}}$ & $3.15^{\mathrm{ab}}$ & $2.96 \pm 0.13$ \\
Globulin, g/dL & $4.90^{\mathrm{a}}$ & $3.10^{\mathrm{bc}}$ & $3.00^{\mathrm{bc}}$ & $4.05^{\mathrm{ab}}$ & $3.30^{\mathrm{bc}}$ & $2.35^{\mathrm{c}}$ & $3.45 \pm 0.26$ \\
A:G ratio & $0.50^{\mathrm{c}}$ & $1.06^{\mathrm{ab}}$ & $0.75^{\mathrm{bc}}$ & $0.80^{\mathrm{bc}}$ & $1.02^{\mathrm{b}}$ & $1.34^{\mathrm{a}}$ & $0.91 \pm 0.07$ \\
HDL, mg/dL & $16.65^{\mathrm{a}}$ & $8.35^{\mathrm{b}}$ & $7.25^{\mathrm{b}}$ & $14.85^{\mathrm{a}}$ & $15.40^{\mathrm{a}}$ & $10.35^{\mathrm{b}}$ & $12.14 \pm 1.00$ \\
Total cholesterol, mg/dL & $115.00^{\mathrm{a}}$ & $93.00^{\mathrm{bc}}$ & $97.00^{\mathrm{b}}$ & $94.00^{\mathrm{b}}$ & $87.00^{\mathrm{bc}}$ & $78.00^{\mathrm{b}}$ & $94.00 \pm 3.18$ \\
GPT, U/L & $82.00^{\mathrm{ab}}$ & $83.00^{\mathrm{ab}}$ & $88.00^{\mathrm{a}}$ & $80.00^{\mathrm{ab}}$ & $93.00^{\mathrm{a}}$ & $72.00^{\mathrm{b}}$ & $83.00 \pm 2.24$ \\
GOT, U/L & $28.00^{\mathrm{a}}$ & $24.00^{\mathrm{ab}}$ & $23.50^{\mathrm{ab}}$ & $20.50^{\mathrm{ab}}$ & $21.50^{\mathrm{ab}}$ & $15.00^{\mathrm{b}}$ & $22.08 \pm 1.37$ \\
Alkaline phosphates, $\mathrm{U} / \mathrm{L}$ & $14.00^{\mathrm{a}}$ & $13.50^{\mathrm{ab}}$ & $12.00^{\mathrm{bc}}$ & $10.50^{\mathrm{c}}$ & $11.00^{\mathrm{c}}$ & $10.50^{\mathrm{c}}$ & $11.92 \pm 0.39$ \\
Creatinine, mg/dL & $0.23^{\mathrm{c}}$ & $0.21^{\mathrm{c}}$ & $0.20^{\mathrm{c}}$ & $0.60^{\mathrm{a}}$ & $0.65^{\mathrm{a}}$ & $0.33^{\mathrm{b}}$ & $0.37 \pm 0.05$
\end{tabular}

$\mathrm{a}, \mathrm{b}$ and $\mathrm{c}$ : means in the same row having different superscripts differ significantly $(P<0.05)$

SEM standard error of mean, $G_{1}$ control, $G_{2}$ contained $0.5 \%$ garlic powder, $G_{3}$ contained $1 \%$ garlic powder, $G_{4}$ contained $1 \%$ onion powder, $G_{5}$ contained $1 \%$ onion powder $+0.5 \%$ garlic powder, $G_{6}$ contained $1 \%$ onion powder $+1 \%$ garlic powder

\section{Lipid content}

Values of high-density lipoprotein (HDL) decreased significantly $(P<0.05)$ with laying hens received ration $0.5 \%$ and $1 \%$ OP and 1\% OP and 1\% GP only. On the other hand, incorporation of GP, OP, and the mixture of them $(P<0.05)$ decreased total cholesterol concentration (Table 5).

\section{Liver function}

Inclusion of $1 \%$ OP $+1 \%$ GP $\left(\mathrm{G}_{6}\right)$ significantly $(P<0.05)$ decreased GOT content; meanwhile, the other treatments $\left(G_{2}\right.$ to $\left.G_{5}\right)$ insignificantly decreased GOT. Incorporation of $1 \% \mathrm{OP}+1 \% \mathrm{GP}\left(\mathrm{G}_{6}\right)$ and $1 \% \mathrm{OP}\left(\mathrm{G}_{4}\right)$ insignificantly decreased GPT (Table 5).

\section{Kidney function}

Except for laying hens received $0.5 \% \mathrm{GP}\left(\mathrm{G}_{2}\right)$, the other dietary treatments significantly $(P<0.05)$ decreased alkaline phosphates. On the other hand, adding $0.5 \%$ or $1 \%$ GP had no significant effect. Meanwhile, supplementation of $1 \% \mathrm{OP}, 1 \% \mathrm{OP}+0.5 \% \mathrm{GP}$, or $1 \% \mathrm{OP}+1 \% \mathrm{GP}$ significantly $(P<0.05)$ increased creatinine (Table 5$)$.

The present results cleared that inclusion of garlic powder in laying hen rations reduced creatinine concentration, because this may be related to garlic having renal protection role against some stress factors and improving its healthy condition, which is probably through its excellent antioxidant properties and highly nutritional values.

\section{Discussion}

The present results of the chemical analysis (Table 2) are within the trend noted by Nwinuka et al. (2005), Dini et al. 2008, Odebunmi et al. (2009), Otunola et al. (2010), Yalcin and Kavuncuoglu (2013), and Sajid et al. (2014) who noted that value of moisture ranged from 3.26 to $3.55 \%$, CP ranged from 7.87 to $8.87 \%$, CF ranged from 4.49 to $4.86 \%$, EE ranged from 0.78 to $0.92 \%$, and ash ranged from 3.36 to $3.73 \%$ for garlic powder. On the other hand, they found that moisture ranged from 2.68 to $2.82 \%$, CP ranged from 6.46 to $6.81 \%$, CF ranged from 5.58 to $5.85 \%$, EE ranged from 0.64 to $0.83 \%$, and ash ranged from 4.23 to $4.46 \%$ for onion powder.

Data concerning with feed intake Table 3 are in agreement with those noted by Khan et al. (2008) who found that supplementation of garlic powder had no effect on the feed consumption in native Desi laying hens. Also, Qureshi et al. (1983) did not report any differences in daily feed consumption of pullets fed diets with various garlic products at levels equal to about $50 \mathrm{~kg} / \mathrm{ton}$ of added garlic bulb. Chowdhury et al. (2002) recorded that feed consumption and feed efficiency were not affected by supplementation of $0,2,4,6,8$, or $10 \%$ garlic paste over the 6-week period.

The present results of feed conversion were in agreement with those attributed by Lewis and Elvin-Lewis (2003) and Demir et al. (2003) who noted an improvement in feed conversion ratio of broilers fed garlic. Meanwhile, Asrat et al. (2018) found that feed conversion was not affected by addition of garlic powder in White Leghorn hens.

It must be mentioned that eggs are delicate product which can lose quality rapidly during the period of collection to consumption. Thus, improvement in egg quality is of paramount importance in the field of production and management (Mahmoud et al. 2010).

There is a dearth of literature available concerning the beneficial effects of garlic or onion on egg quality. For example, Yalcin et al. (2006) noticed that egg weight increased when laying hens were fed 5 and $10 \mathrm{~g} / \mathrm{kg}$ garlic powder. Also, Khan et al. (2007) noted that egg production increased during the 6 weeks in which $0,2,6$, or $8 \%$ garlic powder was fed to laying hens. On the other hand, Canogullari et al. (2010) reported that egg production increased significantly by adding $1 \%$ garlic powder in the feed of laying hen. Meanwhile, Reddy et al. (1991) and 
Chowdhury et al. (2002) noted that the supplementation of garlic powder did not affect egg production.

Results published in Table 4 are in agreement with those found by Canogullari et al. (2010) who demonstrated that egg weight, yolk index, shell weight, shell thickness, and yolk weight did not change when laying hens fed ration containing $1 \%$ garlic powder. On the other hand, Yalcin et al. (2006) reported that the supplementation of garlic had no significant effect on egg albumin index, egg shell index, and egg Haugh unit values when laying hens fed diets containing 5 or $10 \mathrm{~g} / \mathrm{kg}$ garlic powder for 22 weeks.

Values of blood plasma constituents illustrated in Table 5 are near from the results suggested by El-katcha et al. (2016) who revealed that garlic extract (allicin) supplementation at $50 \mathrm{mg} / \mathrm{kg}$ diet significantly increased albumin concentrations, while allicin supplementation at 25 , 75 , or $100 \mathrm{mg} / \mathrm{kg}$ had no significant effect on total protein and albumin concentrations compared with the control.

Data on lipid (Table 5) are in agreement with those found by Ahsan-Ul-Haq et al. (1999) who reported that feeding garlic at the rate of $20 \mathrm{~g} / \mathrm{kg}$ significantly decreased blood cholesterol in broiler chicks. Also, Khan et al. (2008) noted that garlic powder given at the level of $8 \%$ may result in better serum cholesterol profile in laying hens. Moreover, Rehman et al. (2011) noted that a mixture of plants containing garlic as an active ingredient improved the cholesterol profile in terms of cholesterol, triglyceride, and LDL in boiler chicken serum. Konjufca et al. (1997) noticed that feeding a diet supplemented with $1.5,3.0$, or $4.5 \%$ garlic powder resulted in reduced level of plasma cholesterol. Also, Qureshi et al. (1983) found a $28-41 \%$ reduction in low-density lipoprotein (LDL) cholesterol in chickens fed diet containing $3.8 \%$ garlic paste or a solvent extract of garlic paste, the residue, or commercial garlic oil. Also, Horton et al. (1991) reported that broilers fed diet containing 10,000 $\mathrm{mg} / \mathrm{kg}$ decreased their plasma cholesterol content. El-katcha et al. (2016) observed that serum total cholesterol concentration was significantly reduced by about $12.9 \%, 11.9 \%, 7.9 \%$, and $14.2 \%$ when garlic extract was supplemented at $0.1,0.2,0.3$, or $0.4 \mathrm{mg} / \mathrm{kg}$ diet, respectively, to broiler chickens. Reductions in total cholesterol were realized in broilers fed ration supplemented with 1 g garlic/kg feed (Mansoub 2011).

Garlic manifested hypocholesterolemic effects on chickens through inhibition of the most important enzymes that participate in the synthesis of cholesterol and lipids (Stanacev et al. 2011). Also, Konjufca et al. (1997) reported that garlic reduced plasma cholesterol by decreasing the activity of 3-hydroxy-3-methlyglutaryl reductase. Allicin has been proposed as the active compound in garlic responsible for health promotion and hypocholesterolemic benefits (Lawson 1998).
Our results of liver function (Table 5) are in agreement with El-katcha et al. (2016) who reported that higher inclusion rate of allicin $(100 \mathrm{mg} / \mathrm{kg})$ increased $(P<0.05)$ GPT blood serum concentration by about $3.1 \%$ in broiler. On the other hand, Kumar et al. (2013) observed that GOT decreased $(P<0.05)$ when broiler chicken fed diets supplemented by Allium sativum in different treatment group compared to the control group.

Generally, the mechanism by which garlic reduce plasma cholesterol concentration is not fully understood. Some of the investigators had the opinion that garlic depressed lipogenic and cholesterrogenic activities of liver enzymes such as malic enzyme, fatty acid synthase, glucose-6-phosphate dehydrogenase, and 3-hyydroxymethyl-glutaryl-CoA (HMG-CoA) reductase (Chowdhury et al. 2002; Canogullari et al. 2010; Mahmoud et al. 2010; Khan et al. 2012). This hypothesis was demonstrated when several researchers measured cholesterol-clearing enzymes. For example, Konjufca et al. (1997) noted that feeding 3\% commercial garlic powder reduced the activities of HMG-CoA reductase and cholesterol $7 \alpha$-hydroxylase by $40 \%$. Allicin has been proposed as the active compound in garlic responsible for health promotion and hypercholesterolemic benefits (Lawson 1998). In terms of the mechanism of action, it is believed to reduce cholesterol synthesis and plated aggregation and prevent thrombosis (Canogullari et al. 2010). Allicin is a volatile organic compound which has been shown to reduce serum lipids, phospholipids, and cholesterol and suppress cholesterol synthesis in chickens (Horton et al. 1991). Also, according to Mahmoud et al. (2010), the differences in the results may be due to allicin degradation, as it is an unstable compound and poorly absorbed from the gut. Additionally for that, they suggested that the garlic preparation that involved heating or solvent processes may destroy active allicin.

\section{Conclusion}

Under condition suitable for this study and from the results obtained, it can be mentioned that the incorporation of garlic or onion powder or the mixture of them can be safely used with improvement in the general health, egg weight, and feed conversion of hens and decrease in blood cholesterol.

\section{Acknowledgements \\ Our deep thanks for Research and Production Station, National Research Centre for saving facilities that make this work possible. Also, our deep thanks for prof. Dr. Abdel Khalek A. Elghamry for his following up the laying hens through out the experimental period.}

Funding

All authors equally shared in financing the cost of the research paper.

Availability of data and materials

'Not applicable' for that section. 


\section{Authors' contributions}

HAAO co-operated in the plane of work, field work, chemical analysis, arrangement data, and writing and corrected the MS and helped in the publication. SMA co-operated in the plane of work, field work, and revision of the MS and helped in the publication. SSA-M co-operated in the plane of work, field work, revision of the MS and following publication with the Journal (corresponding author). GMHE-M co-operated in the plane of work, field work, data calculations, and statistical analyses. AAB co-operated in the blood sample analysis. MMAF co-operated in determining the egg quality data. All authors read and approved the final manuscript.

\section{Ethics approval and consent to participate}

'Not applicable' for that section.

\section{Consent for publication}

'Not applicable' for that section.

\section{Competing interests}

The authors declare that they have no competing interests.

\section{Publisher's Note}

Springer Nature remains neutral with regard to jurisdictional claims in published maps and institutional affiliations.

\section{Author details}

'Animal Production Department, National Research Centre, 33 El-Bohouth Street, P.O: 12622, Dokki, Cairo, Egypt. ${ }^{2}$ Regional Centre for Food and Feed, Agriculture Research Centre, Ministry of Agriculture, Cairo, Egypt. ${ }^{3}$ Poultry Nutrition Department, Agricultural Research (11268), Animal Production Research Institute, Dokki, Cairo, Egypt.

Received: 1 October 2018 Accepted: 22 January 2019

Published online: 08 February 2019

\section{References}

Abdo MS, Soad AM, El-Nahla MA (1983) Effect of some feed additives on blood constituents of growing Hubbard chickens. Chem Abstr 101:37558 (Abstract.) Abdullah AY, Mahmoud KZ, Nusairat BM, Qudsieh RI (2010) Small intestinal histology, production parameters, and meat quality as influenced by dietary supplementation of garlic (Allium sativum) in broiler chicks. Ital J Anim Sci 9(4):414-419

Ahsan-Ul-Haq, Meraj KA, Rasool S (1999) Effect of supplementing allium sativum (garlic) and Azidirachata indica (Neem) leaves in broiler feeds on their blood cholesterol, triglycerides and antibody titer. Int J Agric Biol 1:125-127

Allain CC, Chan PCS, Richmond W, Fu PC (1974) Enzymatic determination of total serum cholesterol. Clin Chem 20:470-475

Anderson KE, Tharrington JB, Curtis PA, Jones FT (2004) Shell characteristics of eggs from historic strains of single comb white Leghorn chickens and the relationship of egg shape to shell strength. Int J Poult Sci 3:17-19

AOAC (2005) Official methods of analysis, 18th edn. Association of Official Analytical Chemists, Washington, DC

Armstrong WD, Carr CW (1964) Physiological chemistry: laboratory directions 3: 75 Buger Puplishing Co. Minneapolis, Minnesota, U.S.A.

Asrat M, Zeryehun T, Amha N and Urge M (2018) Effects of supplementation of different levels of garlic (Allium sativum) on egg production, egg quality and hatchability of White Leghorn chicken. Livestock Research for Rural Development. Volume 30, Article \#37. Retrieved January 28, 2019, http:// www.lrrd.org/lrrd30/3/tesf30037.htm

Assmann G (1979) HDL-cholesterol precipitant. Randox Labs. Ltd. Crumlin Co. Antrim, N. Ireland. Internist 20:559-567

Beliefield A, Goldberg DM (1971) Estimation of serum alkaline phosphates. Enzyme 12:561

Canogullari S, Baylan M, Erdogan Z, Duzguner V, Kucukgul A (2010) The effects of dietary garlic powder on performance, egg yolk and serum cholesterol concentrations in laying quails. Czeh J Anim Sci 55:286-293

Chowdhury SR, Chowdhury SD, Smith TK (2002) Effects of dietary garlic on cholesterol metabolism in laying hens. Poult Sci 81:1856-1862

Demir E, Sarica S, Ozcan MA, Suicmez M (2003) The use of natural feed additives as alternatives for an antibiotic growth promoter in broiler diet. Br Poult Sci 44(1):544-545
Dewit C, Noterman S, Gorin N, Kampefinacher HE (1979) Effect of garlic oil or onion oil on toxin production by C. botulinum in meat slurry. J Food Prot 45:1007

Dini I, Tenore GC, Dini A (2008) Food Chem 107:613-621

Doumas BL, Watson T, Biggs T (1971) Albumin standards and measurement of serum with bromocresol green. Clin Chem Acta 31:87

Doyon G, Bernier-Cardou M, Hamilton RMG, Eastaigns F, Ramdald CT (1986) Egg quality 2: albumen quality of egg from five commercial strains of White Leghorn hens during one year of lay. Poult Sci 65:63-66

Duncan DB (1955) Multiple range and multiple F-test. Biometrics 11:1-42

El-Feel FMR, Abd El-Ghani AA, El-Barody MAA, Fahmy STM (1999) Effect of feeding onion wastes and virginamycin on growth performance, rumen activity, blood and immunology parameters in growing Frisian and buffalo calves. Alex J Agric Res 44(1):1-16

El-katcha MI, Soltan MA, Sharaf MM, Hasen A (2016) Growth performance, immune response, blood serum parameters, nutrient digestibility and carcass traits of broiler chicken as affected by dietary supplementation of garlic extract (allicin). Alex J Vet Sci 49(2):50-54

El-Nawawi GH (1991) Some of non conventional ingredients in broiler ration. M. Sc. Thesis, Faculty of Agriculture, Ain Shams University

Freeman F, Kodera Y (1995) Garlic chemistry: stability of S-(2-propenyl) 2propene-1-sulfinothioate (allicin) in blood, solvents, and stimulated physiological fluids. J Agric Food Sci 43:2332-2338

Goodarzi M, Landy N, Nanekarani SH (2013) Effect of onion (Allium cepa L.) as an antibiotic growth promoter substitution on performance, immune responses and serum biochemical parameters in broiler chicks. Health 5(8):1210-1215

Grela RR, Klebaniuk R (2007) Chemical composition of garlic preparation and its utilization in piglet diets. Medycyna Wet 63:792-795

Günlü A, Kirikçi K, Çetin O, Garip M (2003) Some external and internal quality characteristics of partridge (A. graeca) eggs. Food Agric Environ 1:197-199

Hanafy MSM, Shalaby SM, El-Fouly MAA, Abdel-Aziz MI, Soliman FA (1994) Effect of garlic on lead contents in chicken tissues. Dtsch Tierarztl Wochenschr 101(4):157

Hariedy MA (1977) Biological and chemical studies on Egyptian onion and garlic. M. Sc. Thesis, Faculty of Agriculture, Cairo University

Harold V (1975) Colorimetric determination of glutamate pyruvate and oxaloacetic transaminase, practical Clin. Biochem, 4th edn, p 294

Horton GMJ, Fennel MJ, Prasad BM (1991) Effects of dietary garlic (Allium sativum) on performance, carcass composition and blood chemistry changes in broiler chickens. Can J Anim Sci 71:939-942

Husdan H (1968) Chemical determination of creatinine with deproteinization. Clin Chem 14:222

Kavindra S, Shalini N, Singh K, Nagaich S (2000) Studies on the anthelmintic activity of Allium sativum (Garlic) oil on common poultry worms Ascaridia galli and Hetrakis gallinae. J Parasitol Appl Anim Biol 9(1):47-52

Kemper KJ (2000) Garlic (Allium sativum) Longwood herbal task force. http:// www.longwoodherbal.org/garlic/garlic.pdf

Kendler BS (1987) Garlic (Allium Sativum) and onion (Allium Cepa). A review of their relationship to cardio vascular disease. Prev Med 16:670-685

Khan QSH, Hassan S, Sardar R, Anjum MA (2008) Effects of dietary garlic on cholesterol concentration in native Desi laying hens. Am J Food Technol 3: 207-2013

Khan RU, Nikousefat Z, Tufarelli V, NAZ S, Javdani M, Laudadio V (2012) Garlic (Allium sativum) supplementation in poultry diets: effect on production and physiology. Worlds Poult Sci J 68:417-424

Khan SH, Sardar R, Anjum MA (2007) Effects of dietary garlic on performance and serum and egg cholesterol concentration in laying hens. Asian Aust J Anim Sci 21:22-27

Konjufca VH, Pesti GM, Bakalli RI (1997) Modulation of cholesterol levels in broiler meat by dietary garlic and copper. Poult Sci 76:1264-1271

Koremura N, Hasegawa T, Suzuki T (1984) Studies on the growth stimulating material in onion to rat. Nutr Abstr Rev 54:5019

Kumar S, Kumar A, Chandra A (2013) Alteration in serum biochemical parameters due to garlic (Allium sativum) supplementation in broilers' diets. Afr J Biotechnol 12(29):4691-4698

Kumar S, Sharadamma KC, Radhakrishna PM (2010) Effects of a garlic active based growth promoter on growth performance and specific pathogenic intestinal microbial counts of broiler chicks. Int J Poult Sci 9:244-246

Lampe JW (1999) Health effects of vegetables and fruits: assessing mechanisms of action in human experimental studies. Am J Clin Nutr 70:475-490 
Lawson LD (1998) Garlic: a review of its medicinal effects and indicated active compounds. In: Lawson LD, Bauer R (eds) Phytomedicines of Europe: chemistry and biological activity, Washington, ACS symposium series, USA, vol 91, pp 176-209

Lewis W and Elvin-Lewis M (2003) Medical botany plants affecting human health, 2nd edn. Wiley, New York

Lim KS, You SJ, An BK, Kang CW (2006) Effects of dietary garlic powder and copper on cholesterol content and quality characteristics of chicken eggs. Asian Aust J Anim Sci 19:582-586

Mahmoud KZ, Saad M, Gharaibeh H, Zakaria A, Amer M (2010) Garlic (Allium sativum) supplementation: influence on egg production, quality and yolk cholesterol level in laying hens. Aust J Anim Sci 23:1503-1509

Mansoub NH (2011) Comparative effects of using garlic as probiotic on performance and serum composition of broiler chickens. Ann Biol Res 2:486-490

Melvin JM, Jayochitra J, Vijayapriaya M (2009) Antimicrobial activity of some common spices against certain human pathogens. J Med Plant Res 3:1134-1136

NRC (1994) Nutrient Requirements of Poultry. Ninth Revised Edition. Subcommittee on Poultry Nutrition Committee on Animal Nutrition. Board on Agriculture, National Research Council, National Academy Press, Washington, D.C.

Nwinuka NM, Ibeh GO, Ekeke Gl (2005) Proximate composition and levels of some toxicants in four commonly consumed spices. J Appl Sci Environ 9(1): 150-155

Odebunmi EO, Oluwaniyi OO, Bashiru MO (2009) Comparative proximate analysis of some food condiments. J Appl Sci Res 2(1):1-3

Osman AMA, Galal AGH, Mohamed K, Ayoub FM (1997) The use of onion in the diets of broiler chickens. Egyptian J Nutrition and feeding, pp289-298 Special issue, Proc 6th conference on Animal Nutrition, El-Minia, 17-19 Nov

Otunola GA, Oloyede OB, Adenike T, Oladiji T, Afolayan AJ (2010) Comparative analysis of the chemical composition of three spices Allium sativum, Zingiber officinale Rosc and Capsicum frutescens L. commonly consumed in Nigeria. Afr J Biotechnol 9(41):6927-6931

Pisani T, Gebski CP, Leary ET (1995) Accurate direct determination of low-density lipoprotein, cholesterol assay. Arch Pathol Lab Med 119:1127

Popić M (2009) Hemijski sastav belog i crnog luka. Tehnologija hrane 2:42-47

Qureshi AA, Din ZZ, Abuirmeileh N, Burger WC, Ahmad Y, Elson CE (1983) Suppression of avian hepatic lipid metabolism by solvent extracts of garlic: impact on serum lipids. J Nutr 113:1746-1755

Reddy RV, Lightest SF, Maurice DV (1991) Effect of feeding garlic oil on performance and egg yolk cholesterol concentration. Poult Sci 70:2006-2009

Rehman S, Durrani FR, Chand N, Khan RU, Rehman F (2011) Comparative efficacy of different schedules of administration of medicinal plants infusion on hematology and serum biochemistry of broiler chicks. Res Opin Anim Vet Sci 1:8-14

Reitman S, Frankel S (1957) Calorimetric method for the determination of serum glutamic oxaloacetic and glutamic pyruvate transaminase. An J Clin Path 28:56

Rode H, Wet PM, Cywes SD, Dewit PM (1989) The antimicrobial effect of Allium Sativum L. (garlic). S Afr J Sci 85(7):462

Sajid M, Butt MS, Shehzad A, Tanweer S (2014) Chemical and mineral analysis of garlic: a golden herb. Pak J Food Sci 24(Issue 1):108-110

Sivam GP (2001) Protection against Helicobacter pylori and other bacterial infections by garlic. J Nutr 131:1106-1108

SPSS (2008) Statistical package for Social Sciences, Statistics for Windows, version 17.0. Released 2008. SPSS Inc, Chicago

Stanacev V, Glamocic D, Milosevic N, Puvaca N, Stanacev V, Plavsa N (2011) Effect of garlic (Allium sativum L.) in fattening chicks nutrition. Afr J Agric Res 6 : 943-948

Stanaćev V., Milošević N, Plavša N, Bjedov S, Stanaćev V, Puvača N, Arapović Ž (2010) Phyto additives (Allium Sativum L.) in the diet of fattening chickens. XIV international symposium feed technology, Novi Sad, Proceedings 295-301

Tietz NW (1986) A method for the rapid determination of albumin of blood plasma. P.589 in textbook of clinical chemistry. W.B. Saunders company, Philadelphia

Witt I, Trendelenburg C (1982) A method for the rapid determination of total protein plasma. J Clin Biochem 20:235

Yalcin H, Kavuncuoglu H (2013) Physical, chemical and bioactive properties of onion (Allium cepa L.) seed and seed oil. Recent Res Devel Lipids 9:53-65

Yalcin S, Onbasilar EE, Reisli Z, Yalcin S (2006) Effects of garlic powder on the performance, egg traits and blood parameters of laying hens. J Sci Food Agric 86:1336-1339

\section{Submit your manuscript to a SpringerOpen ${ }^{\circ}$ journal and benefit from:}

- Convenient online submission

- Rigorous peer review

- Open access: articles freely available online

- High visibility within the field

- Retaining the copyright to your article

Submit your next manuscript at $>$ springeropen.com 